\section{Audiência pública na ADPF 422: análise dos argumentos relacionados à descriminalização do aborto}

Vaserino, Débora Karina Gonçalves

Mestranda do programa de pós-graduação em Direito da Faculdade de Ciências Humanas e Sociais (FCHS) UNESP/Franca-SP.E-mail: deboravaserino@gmail.com.

\section{Marchetto, Patrícia Borba}

Professora Doutora do programa de pós-graduação em Direito da Faculdade de Ciências Humanas e Sociais (FCHS) - UNESP/Franca-SP

PALAVRAS-CHAVE: Aborto; Descriminalização; STF; Desigualdade social; Direito penal mínimo.

Introdução - A arguição de descumprimento de preceito fundamental 422 pretende que o STF exclua do âmbito de incidência dos artigos 124 e 126 do Código Penal a interrupção da gestação induzida e voluntária realizada nas primeiras 12 semanas. A ação argumenta que os artigos que proíbem o aborto afrontam preceitos fundamentais da Constituição Federal de 1988. Objetivo - Analisar os argumentos apresentados por especialistas, instituições e organizações na audiência pública realizada nos dias 03 e 06 de agosto de 2018 na Primeira Turma do STF para contribuir, de forma dialógica, com a discussão sobre a descriminalização do aborto. Métodos - Neste trabalho, utilizamos o método dialético, através da investigação da contraposição dos argumentos conflitantes no âmbito da referida audiência pública para posterior compreensão do papel dos mesmos na discussão do tema. A audiência pública objeto da pesquisa está disponível no canal do STF no YouTube em quatro vídeos publicados em 06 de agosto de 2018. O trabalho insere-se na área temática 9, Bioética e Política. Resultados - Após dois dias de audiência, mais de 40 especialistas do Brasil e do exterior, entre eles pesquisadores de diversas áreas, profissionais da saúde, juristas, advogados e representantes de organizações da sociedade civil de defesa dos direitos humanos e entidades de natureza religiosa, fizeram suas exposições, nas quais a maioria se manifestou a favor da descriminalização do aborto. Conclusões - A proposta da ADPF é para descriminalização do aborto, ou seja, retirar a questão da esfera do direito penal. Não se confunde com a legalização, que determinaria a forma pela qual o aborto poderia ser feito, incluindo os procedimentos realizados pelo SUS. Retirar a questão do âmbito criminal pode evitar a morte de mulheres que, por medo da ação penal, não procuram o serviço de saúde no caso de complicação decorrente da prática do aborto. $\mathrm{O}$ foco passa a ser a saúde e a consciência da mulher no total exercício dos seus direitos reprodutivos. Além disso, a criminalização do aborto fica restrita às mulheres que não possuem condição de se locomover até países em que a prática não é considerada crime. Logo, a questão penal recai sobre seguimentos sociais específicos, o que indiretamente contribui para disparidade entre ricos e pobres. Entendemos que o direito ao planejamento familiar não pode ser condicionado à classe social a qual a pessoa pertence. A questão passa a ser financeira, no sentido de que uma pessoa abastada pode se deslocar e abortar em um país em que a prática não seja crime. Por fim, tendo em vista que o direito penal é tutelado pelo princípio do direito penal mínimo e considerando ainda que a prática do aborto é recorrente na atual sociedade brasileira, não cabe mais considerar tal ato crime quando há consentimento da gestante. Desta forma, concluímos pela procedência da ADPF 422.

\section{AGRADECIMENTOS}

Ao programa de pós-graduação em Direito da Faculdade de Ciências Humanas e Sociais (FCHS) - UNESP/Franca-SP pelo espaço e tempo fundamentais à elaboração deste trabalho.

\section{REFERÊNCIAS}

[1] K. F. Anjos, V. C. Santos, R. Souza e B. G. Eugênio, Saúde em Debate. 37, 504 (2013).

[2] T. L. Beauchamp e J. F. Childress, Oxford University Press.7 (2013).

[3] D. Diniz e A. C. G. Vélez, Rev. Estudos Feministas. 16, 647 (2008).

[4] J. J. Thomson, Rev. Bras. Ciênc. Polít. 7 (2012).

[5] H. Veiga Junior e P. B. Marchetto, Rev. Quaestio Iuris. 10, 1181 (2017). 